\title{
ГАРМОНІЙНИЙ ІННОВАЦІЙНИЙ РОЗВИТОК ЕКОНОМІКИ УКРАЇНИ ЗА УМОВ ЄВРОІНТЕГРУВАННЯ: ПРОБЛЕМИ ТА ПЕРСПЕКТИВИ
}

\author{
HARMONIOUS INNOVATIVE DEVELOPMENT \\ OF UKRAINE'S ECONOMY IN THE CONDITIONS \\ OF EUROPEAN INTEGRATION: \\ PROBLEMS AND PROSPECTS
}

\author{
Завербний Андрій Степанович \\ доктор економічних наук, профессор, \\ Національний університет «Львівська політехніка» \\ ORCID: https://orcid.org/0000-0001-7307-536X \\ Білець Леся Володимирівна \\ студентка, \\ Національний університет «Львівська політехніка» \\ ORCID: https://orcid.org/0000-0001-6116-8307 \\ Налутка Павло Васильович \\ студент, \\ Національний університет «Львівська політехніка» \\ ORCID: https://orcid.org/0000-0002-8842-4232
Zaverbnyj Andrij, Bilets Lesya, Nalutka Pavlo
Lviv Polytechnic National University

\begin{abstract}
Стаття присвячена аналізуванню проблем, перспектив гармонійного інноваційного розвитку економіки України за умов євроінтегрування. Досліджено фрактори, що впливають на інноваційний розвиток країни. Визначено термінологію гармонізування інноваційного розвитку на противагу сталості (незмінності) розвитку. В роботі проаналізовано динаміку і структуру фрінансування інноваційної сорери України за період 2010-2020 рр. Проаналізовано частку у ВВП витрат спрямованих на науково-дослідні роботи в Україні за аналогічний період. Здійснена порівняльна характеристика даних витрат із країнами ЄС. Для удосконалення управління інноваційним розвитком економіки України доцільним класифіковано чинники, які впливають на нього за євроінтеграційних умов. Активізування інноваційної діяльності в Україні вимагає комплексного управлінського підходу.

Ключові слова: гармонійний розвиток, інновації, інноваційна діяльність, індикатори інноваційної діяльності, інноваційний розвиток, євроінтеграція.
\end{abstract}

Статья посвящена анализу проблем, перспектив гармоничного инновационного развития экономики Украины в условиях евроинтегрирования. Исследованы фракторы, влияющие на инновационное развитие страны. Определена терминология гармонизации инновационного развития в противоположность постоянству (неизменности) развития. В работе проанализирована динамика и структура фринансирования инновационной сфееры Украины за период 2010-2020 гг. Проанализирована доля в ВВП расходов направленных на научно-исследовательские работы в Украине за аналогичный период. Произведена сравнительная характеристика данных расходов со странами ЕС. Для усовершенствования управления инновационным развитием экономики Украины целесообразно классифицированы фракторы, которые влияют на него при евроинтеграционных условиях. Активизация инновационной деятельности в Украине требует комплексного управленческого подхода.

Ключевые слова: гармоничное развитие, инновации, инновационная деятельность, индикаторы инновационной деятельности, инновационное развитие, евроинтеграция.

The article is devoted to the analysis of problems, prospects of harmonious innovative development of the economy of Ukraine in the conditions of European integration. Today, Ukraine lags far behind in the harmonious 
development of the innovation sphere in the following main components: the level of labor productivity, financial support of the innovation sphere. The factors influencing the innovative development of the country are investigated in the work. The terminology of harmonization of innovative development as opposed to sustainability (invariability) of development is defined. The paper analyzes the dynamics and structure of financing of the innovation sphere of Ukraine for the period 2010-2020. The share of GDP expenditures on research in Ukraine for the same period is analyzed. To improve the management of innovative development of Ukraine's economy, it is advisable to classify the factors that affect it in terms of European integration. The positive factors include human resources (this factor is recognized by European experts), a scientific complex that still (despite these negative factors) retains a high level of ability (potential) to effectively produce results (even globally). These factors will determine the choice made by potential investors, sources of investment innovations, will determine the required amount of investment in innovation development, will form the conditions for investment support of innovations. To solve the existing problems it is necessary to understand what factors contribute / constrain innovative development and on this basis to build an innovation strategy. The comparative characteristic of these expenses with the EU countries is carried out. To improve the management of innovative development of Ukraine's economy, it is expedient to classify the factors that affect it under the conditions of European integration. Intensification of innovation activity in Ukraine requires a comprehensive management approach, which will be based on factor analysis, will clearly define the state priority in innovation activity. It is necessary to develop and implement comprehensive measures to financially stimulate innovation at the state level, create favorable conditions for modernization of production, commercialization of scientific developments and ideas, active involvement of research structures in the implementation of innovative projects and more.

Keywords: harmonious development, innovations, innovative activity, indicators of innovative activity, innovative development, European integration.

Постановка проблеми. Динамічні процеси адаптування економіки України за умов євроінтегрування вимагають активного впровадження інновацій задля втримання країною конкурентоспроможності. Тому проблематика інноваційного розвитку сьогодні $€$ надзвичайно актуальною.

Аналіз останніх досліджень і публікацій. Дослідженню інноваційного розвитку в економіці України $€$ присвяченою низка наукових праць. Вагомі внески у розроблення наукового, методологічного забезпечення розвитку інновацій в економіці в т.ч. й нашої країни зробили такі вчені економісти, як, Адамова 3.О. [1], Алєксєєв І.В. [3], Амоша О.І. [2], Антонюк В.П. [2], Вавіліна Н.І. [7], Вітковська К.В. [14], Ворона А.В. [4], Геєць В.М. [5], Грачова Ю.М. [17], Гуржій А.М. [7], Желізняк Р.Й. [3], Землянкін А.І. [2], Каракай Ю.В. [7], Квак С.А. [8], Коваленко А.С. [8], Колеватова А.В. [8], Костецький В. [10], Кравець А.І. [13], Куранда Т.К. [7], Лапко О.О. [11], Леховіцер В.О. [12], Мазур А.В. [3], Манаєнко І.М. [13], Ольвінська Ю.О. [14], Петренко З.О. [7], Примаченко І. [10], Самотоєнкова О.В. [14], Скляров Р. [16], Соляник Л.Г. [17], Юринець 3.В. [18] та багато інших.

Виділення невирішених раніше частин загальної проблеми. Одночасно окремі методологічні і практичні аспекти гармонійного розвитку інноваційної діяльності економіки нашої країни, вплив на нього ключових чинників саме за євроінтеграційних умов потребують детальнішого дослідження із урахуванням високого рівня динамічності даної сорери.
Формулювання цілей статті (постановка завдання). Основними цілями статті $\epsilon$ ідентифікування проблем, що постають на шляху гармонійного інноваційного розвитку економіки України за умов євроінтегрування, дослідження основних фракторів, що впливають на цей процес, виявлення перспектив подальшого їх використання задля їх вирішення.

Виклад основного матеріалу дослідження. На сьогодні Україна суттєво відстає у гармонійному розвитку інноваційної ссрери за такими основними складовими: рівень продуктивності праці, фрінансове забезпечення інноваційної сорери. А як показує аналізування досвіду розвинених країн за сучасних високо динамічних умов економічне зростання, розвиток можна досягнути виключно базуючись на гармонійному інноваційному розвитку. Саме тому необхідно Україні необхідно приділити активну увагу розвитку інноваційної діяльності. Протягом останнього десятиліття левова частка фрінансування інноваційної діяльності в нашій країні відбувалася виключно за рахунок власних коштів промислових підприємств (рис. 1) [15]. Винятком були обсяги інвестицій у 2010 р. іноземних інвесторів (30\%), інші джерела (45\%) у 2011 р. Із 2014 р. частка власних коштів щорічно становила близько 90 \% [15]. Дана проблема, низька продуктивність в інноватиці України є пов'язана із низьким рівнем системи управління інноваційною діяльністю.

Що стосується обсягів фрінансування інновацій, наукових розробок (рис. 2), Україна перебуває на останній позиції зі всіх країн $€$ С. Починаючи із 2013 р. спостерігається тенден- 


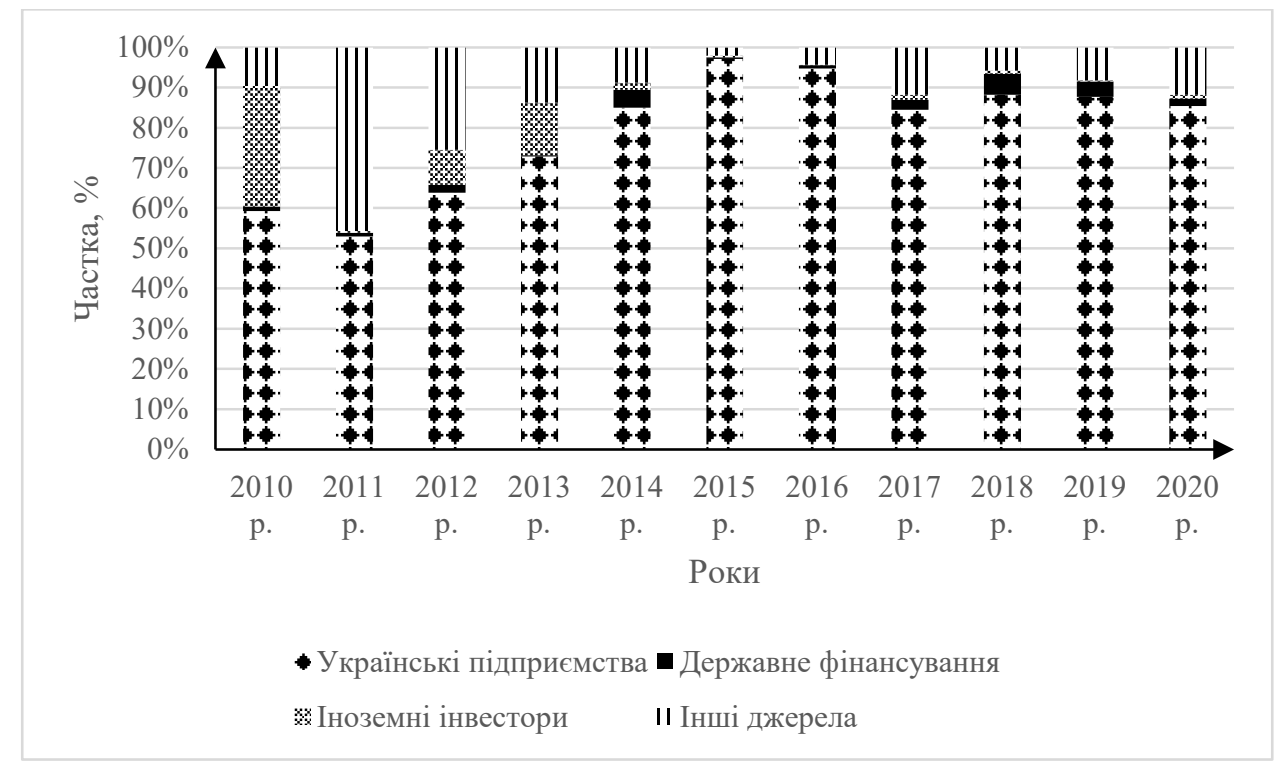

Рис. 1. Структура фрінансування інноваційної сфери за період 2010-2020 рр.

Джерело: [15]

ція щодо різкого падіння частки у ВВП витрат спрямованих на науково-дослідні роботи в Україні (рис. 2) [15]. Дана тенденція є надзвичайно незадовільною особливо за умов євроінтегрування, адже критерій витрат на науково-дослідні роботи в ЄС (закладений та затверджений стратегією «Європа 2020») становить 3\% ВВП [19, с. 9]. В Україні цей індикатор становив 0,41 \% у 2020 р. [15]. Необхідно вирішувати ці проблеми шляхом формування есрективної та дієвої інноваційної стратегії.
Для удосконалення управління інноваційним розвитком економіки доцільним $є$ класифрікування чинників, які впливають на нього за євроінтеграційних умов. Задля вирішення існуючих проблем потрібно розуміти які ж саме чинники сприяють/стримують інноваційний розвиток та на основі цього вибудовувати інноваційну стратегію. Передусім потрібно визначити чинники негативного впливу. До них відносяться [8, с. 116-117]: обмеженість попиту на українську інноваційну продукцію

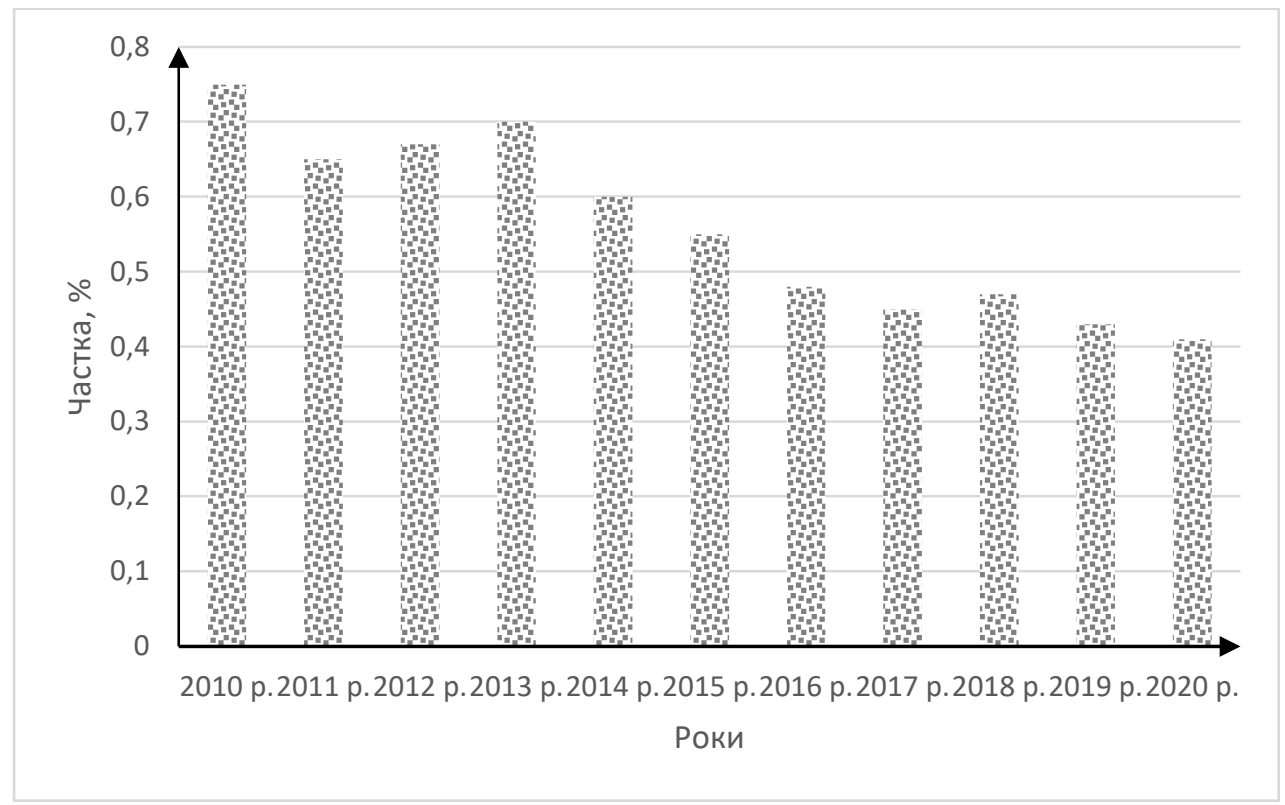

Рис. 2. Частка у ВВП витрат спрямованих на науково-дослідні роботи в Україні за період 2010-2020 рр., \% 
в нашій країні, низький рівень платоспроможності українських споживачів, обмеженість фрінансування інноваційної діяльності із держбюджету, відсутність фрінансування інноваційних змін, низький рівень зацікавленості фрінансових систем щодо підтримання вітчизняних інноваційних проєктів, високий рівень конкуренції на ринку України з боку провідних іноземних фрірм (зокрема із ЄС) розробників новітніх технологій, відсутність дієвих механізмів державного стимулювання розвитку інноваційної діяльності вітчизняними організаціями, низький рівень комерціалізування вітчизняних інноваційних розробок, ідей (як наслідок, інноваційна пасивність потенційних суб'єктів) тощо.

До позитивних чинників доцільно віднести людські ресурси (цей чинник взнається і європейськими експертами), науковий комплекс, який ще й досі (не дивлячись на перелічені негативні чинники) зберігає високий рівень здатності (потенціалу) ефрективно продукувати результати (навіть на світовому рівні).

Вітчизняна інноваційна ссрера потребує активного інвестування. Цікава позиція вчених Соляник Л.Г. та Грачової Ю.М. [17] щодо чинників, які визначають інвестиційну підтримку інноваційної діяльності. Проаналізувавши специфічність інвестування інновацій, робимо висновки, що особливості інвестиційного фрінансування інноваційного розвитку обумовлюються такими чинниками: рівень значущості інновацій, необхідний обсяг інвестування в інновації, рівень ризиковості інновацій, готовність інновацій до подальшого реалізування, характер ефректу від запровадження інновацій, розмір (масштаб) ефректу від запровадження інновацій тощо. Ці фрактори обумовлюватимуть вибір, який здійснюватимуть потенційні інвестори, джерела інвестування інновацій, визначатимуть необхідний обсяг інвестицій інноваційного розвитку, форму- ватимуть умови інвестиційного підтримання інновацій.

Термін «гармонійний» розвиток вживається на противагу «сталому» (що означає сталий/ незмінний, який апріорі не може бути розвиток). Просто невдалий переклад «сталий» вкоренився у вчених економістів, правовому полі. Якщо проаналізувати цей термін, то Дейлі ґ. у економічній теорії [6] власне говорив саме про гармонійний (а не сталий) розвиток.

Задля стимулювання гармонійного розвитку інноваційної сорери на мікрорівні (в промисловості) передусім необхідно $[2 ; 4 ; 8 ; 9 ; 10 ; 14]$ мотивувати працівників для ефективної інноваційної діяльності, знизити рівень емігрування науковців, вчених, срахівців, законодавче ресрормування галузі інноваційної діяльності (реальні пільги, стимули (приміром, зниження рівня оподаткування підприємств, що розвиваються, проводять інноваційну діяльність, удосконалення амортизаційної політики тощо), розширення джерел фрінансування інновацій, налагодження співпраці із іноземними (в т.ч. із ЄС) підприємствами, обмін передовим досвідом, активізування інноваційної діяльності державною підтримкою, надання інноваційно активним вітчизняним підприємствам кредитів за зниженими ставками тощо.

Висновки. Активізування інноваційної діяльності України вимагає комплексного управлінського підходу, на основі фракторного аналізування, чітку державну пріоритетність інноваційній діяльності. Необхідно розробити та реалізувати комплексні заходи щодо фрінансового стимулювання на державному рівні інноваційної діяльності, створення сприятливих умов для модернізування виробництва, комерціалізування наукових розробок та ідей, активного залучення науково-дослідних структур до реалізування інноваційних проектів, покращити інвестиційний клімат країни тощо.

\section{СПИСОК ВИКОРИСТАНИХ ДЖЕРЕЛ:}

1. Адамова 3.О. Инновационные стратегии экономического развития в условиях глобализации. Симферополь : Крымучпедгиз, 2005. 504 с.

2. Амоша О.І., Антонюк В.П., Землянкін А.І. Активізація інноваційної діяльності: організаційно-правове та соціально-економічне забезпечення. Донецьк, 2007. 328 с.

3. Алєксєєв І.В., Желізняк Р.Й., Мазур А.В. Міжнародна податкова конкуренція в ссрері стимулювання інноваційної діяльності підприємств. Формування ринкової економіки в Україні. 2016. № 8(182). С. 23-33.

4. Ворона А.В. Інноваційна активність підприємств як перспектива розвитку національної економіки України. Ефективна економіка. 2020. № 3. URL: http://www.economy.nayka.com.ua/pdf/3_2020/157.pdf

5. Геєць В.М. Інституційна обумовленість інноваційних процесів у промисловому розвитку України. Економіка України. 2014. № 12. С. 4-19.

6. Дейлі Ґ. Поза зростанням. Економічна теорія сталого розвитку. / пер. Київ : Інтелсфрера, 2002. 234 с. 
7. Гуржій А.М., Каракай Ю.В., Петренко 3.О., Вавіліна Н.І., Куранда Т.К. Інноваційна діяльність в Україні. Київ : УкрIHTEI, 2006. 151 с.

8. Квак С.А. Економічний механізм стимулювання інноваційної діяльності промислових підприємств України : дис. ... канд. екон. наук : 08.00.03. Львів, 2020. 289 с.

9. Колеватова А.В., Коваленко А.С. Проблеми розвитку наукової та інноваційної діяльності в Україні, основні шляхи їх подолання. Науковий вісник Ужгородського національного університету. 2019. Випуск 23. Частина 1. С. 130-134.

10. Костецький В., Примаченко І. Сучасні аспекти пошуку стимулів до інноваційної діяльності суб'єктів господарювання. Світ фрінансів. 2020. № 2. С. 134-144.

11. Лапко О.О. Проектне фрінансування як інноваційний механізм реалізації інвестиційних проектів. Наукові записки Національного університету «Острозька академія». Економіка. 2017. Вип. 4. С. 165-170.

12. Леховіцер В.О. Методичні основи оцінки впливу фракторів на інноваційний розвиток машинобудування. Науковий вісник Херсонського державного університету. 2017. Випуск 25. Частина 1. С. 156-158.

13. Манаєнко І.М., Кравець А.І. Фінансування інноваційної діяльності підприємств: українські реалії та досвід ЄС. Економіка та управління підприємствами. 2018. № 5. С. 109-115.

14. Ольвінська Ю.О., Самотоєнкова О.В., Вітковська К.В. Сучасний стан та тенденції розвитку інноваційної діяльності в Україні. Економіка та держава. 2021. № 4. С. 64-71.

15. Офріційний сайт Державної служби статистики України. URL: http://www.ukrstat.gov.ua/ (дата звернення: 26.10.2021).

16. Скляров Р. Інноваційні парки: досвід України і світу. Бізнес. 03.07.2019. URL: https://business.ua/ strategies/5757-innovatsijni-parki-dosvidukrajini-ta-svitu

17. Соляник Л.Г., Грачова Ю.М. Аналіз машинобудівного комплексу України: основні тенденції інвестиційної та інноваційної діяльності в галузі. URL: http://www.rusnauka.com/31_PRNT_2008 Economics/36566.doc.htm

18. Юринець 3.В. Інноваційні стратегії в системі підвищення конкурентоспроможності економіки України : дис. ... д-ра екон. наук : 08.00.03. Львів : ЛНУ ім. І. Франка, 2017. 460 с. URL: https://www.Inu.edu.ua/wpcontent/ uploads/2016/11/dis_yurynets.pdf

19. Europe 2020. A European strategy for smart, sustainable and inclusive growth. URL: https://ec.europa.eu/ eu2020/pdf/COMPLET\%20EN\%20BARROSO\%20\%20\%20007\%20-\%20Europe\%202020\%20-\%20EN\%20 version.pdf

\section{REFERENCES:}

1. Adamova Z.O. (2005) Innovacionnye stratgii ekonomicheskogo razvitia v uslovijakh globalizacii [Innovation strategies for economic development in the minds of globalization]. Simferopol: Krymuchpedgiz, 504 p. (in Russian)

2. Amosha O. I., Antoniuk V.P., Zemliankin A.I. (2007) Aktyvizacija innovasijnoi diialnosti: organizacijno-pravove ta socialno-ekonomichne zabzpechennia [Activation of innovative activity: organizational and legal and socio-economic support]. Doneck. (in Ukrainian)

3. Alekseev I.V., Zhelizniak R.J., Mazur A.V. (2016) Miznarodna podatkova konkurencia v spheri stymuliuvannia innovacijnoi diyalnosti pidpryyemstv [International tax competition in the field of stimulating innovative activity of enterprises]. Formuvannia rynkovoi ekonomiky $v$ Ukraini, 8, 23-33. (in Ukrainian)

4. Vorona A.V. (2020) Innovacijna aktyvnist pidpryyemstv yak perspektyva rozvytku nacionalnoi ekonomiky Ukrainy [Innovative activity of enterprises as a prospect for the development of the national economy of Ukraine]. Efektyvna ekonomika, 3. Available at: http://www.economy.nayka.com.ua/pdf/3_2020/157.pdf (in Ukrainian)

5. Geyec V.M. (2014) Instytucijna obumovlenist innovacijnykh procesiv u promyslovomu rozvytku Ukrainy [Institutional conditionality of innovation processes in the industrial development of Ukraine]. Ekonomika Ukrainy, 12, 4-19. (in Ukrainian)

6. Dejli G. (2002) Poza zrostaniam. Ekonomichna teoria stalogo rozvytku [Out of growth. Economic theory of sustainable development]. 234 p. (in Ukrainian)

7. Gurzhij A.M., Karakaj Yu.V., Petrenko Z.O. (2006) Innovasijna diyalnist v Ukraini [Innovative activity in Ukraine]. Kyiv. (in Ukrainian)

8. Kvak S.A. (2020) Ekonomichnyi mekhanizm stymuliuvannia innovacijnoi diyalnosti promyslovykh pidpryiemstv Ukrainy [Economic mechanism of stimulation of innovative activity of industrial enterprises of Ukraine]. Candidate's thesis. Lviv. (in Ukrainian)

9. Kolevatova A.V., Kovalenko A.C. (2019) Problemy rozvytku naukovoi ta innovacijnoi diyalnosti v Ukraini, osnovni shliakhy ikh podolannia [Problems of development of scientific and innovative activity in Ukraine, the basic ways of their overcoming]. Naukovyj visnyk Uzgorodskogo nacionalnogo universytetu, 23, 130-134. (in Ukrainian) 
10. Kosteckyj V., Prymachenko I. (2020) Cuchasni aspekty poshuku stymuliv do innovacijnoi dijalnosti subjektiv gospodaruvannia [Modern aspects of finding incentives for innovation of business entities]. Svit finansiv, 2, 134-144. (in Ukrainian)

11. Lapko O.O. (2017) Proektne finansuvannia yak innovacijnyj mekhanizm realizacii investycijnykh prektiv [Project financing as an innovative mechanism for implementing investment projects]. Naukovi zapysky Nacionalnogo universytetu "Ostroz'ka akademia". Ekonomika, 4, 165-170. (in Ukrainian)

12. Lekhovicer V.O. (2017) Metodychni osnovy ocinky vplyvu faktoriv na innovacijnyj rozvytok mashynobuduvannia [Methodical bases of estimation of influence of factors on innovative development of mechanical engineering]. Naukovyj visnyk Khersonskogo derzavnogo universytetu, 25-1, 156-158. (in Ukrainian)

13. Manayenko I.M., Kravec A.I. (2018) Finansuvannia innovacijnoi diyalnosti pidpryjemstv: ukrainski realii ta dosvid ES [Financing of innovative activity of enterprises: Ukrainian realities and experience of the EU]. Ekonomika ta upravlinnia pidpryjemstvamy, 5, 109-115. (in Ukrainian)

14. Olvinska Yu.O., Samotoyenkova O.V., Vitkovska K.V. (2021) Suchazny stan ta tendencii rozvytku innovacijnoi diyalnosti v Ukraini [Current state and trends in the development of innovation in Ukraine]. Ekonomika ta derzhava, 4, 64-71. (in Ukrainian)

15. Oficijnyi sajt Derzavnoi sluzby statystyky Ukrainy [Official site of the State Statistics Service of Ukraine]. Available at: http://www.ukrstat.gov.ual (accessed 26 October 2021). (in Ukrainian)

16. Sklyarov R. (2019) Innovasijni parky: dosvid Ukrainy i svitu [Innovation parks: the experience of Ukraine and the world]. Biznes. Available at: https://business.ua/strategies/5757-innovatsijni-parki-dosvidukrajini-ta-svitu (in Ukrainian)

17. Solyanyk L.G., Grachova Yu.M. (2008) Analiz mashynobudivnogo kompleksu Ukrainy: osnovni tendencii investycijnoi ta innovacijnoi diyalnosti $v$ galuzi [Analysis of the machine-building complex of Ukraine: the main trends of investment and innovation activities in the industry]. Available at: http://www.rusnauka.com/31_PRNT_2008/Economics/36566.doc.htm (in Ukrainian)

18. Yurynec Z.V. (2017) Innovacijni strategii v systemi pidvyshennia konkurentospromoznosti ekonomiky Ukrainy [Innovative strategies in the system of increasing the competitiveness of Ukraine's economy]. Doctor's thesis. Lviv. Available at: https://www.Inu.edu.ua/wpcontent/uploads/2016/11/dis_yurynets.pdf (in Ukrainian)

19. Europe 2020. A European strategy for smart, sustainable and inclusive growth. Available at: https://ec.europa.eu/eu2020/pdf/COMPLET\%20EN\%20BARROSO\%20\%20\%20007\%20-\%20Europe\%202020\% 20-\%20EN\%20version.pdf 